\title{
BEES, HONEY AND HEALTH IN ANTIQUITY
}

\author{
L Cilliers \& F P Retief (University of the Free State)
}

\section{Introduction}

In antiquity bees and honey had a very special significance. Honey was indeed considered to drip from heaven as the food of the gods. As an infant Zeus was fed on honey in the cave of Dicte, by bees and the beautiful Melissa, whose name became the Greek word for "bee". When the ancient Romans wished you luck they said "May honey drip on you!" and for the Israelites Palestine was a "land of milk and honey" (Forbes 1957:85-87). In his Georgics Vergil likened the inhabitants of the new Golden Age to an orderly swarm of bees (Johnson 1980:90-105), and the word "honeymoon" probably derived from the ancient custom of newlyweds to drink mead (honey-wine) for a month after their wedding (Hajar 2002:5-6). Allsop and Miller state that even today honey is popularly associated with warmth, nostalgia, goodness and flattery (1996:513-520).

In this study the origins of apiculture (bee-keeping) and the status and uses of honey in antiquity are analysed - with emphasis on its assumed value as a health promoting agent.

\section{Origins of apiculture and honey}

The earliest evidence of man's involvement with honey-gathering may be found on a pre-historic painting in the Spider Cave at Arena, Spain; this is thought to date back to 10000 BC (Allsop \& Miller 1996:513).

The earliest clear record of apiculture is recorded on a bass-relief in the Sun Temple, Ne-Woser-Re, Egypt, dating back to approximately 2400 BC Archeologists have also found evidence of honey in Egyptian "beer-bread" (2000 BC). The Old Testament's references to honey in the Semitic world, probably originated from the late second millennium BC (Allsop \& Miller 1996:513-515).

Honey is mentioned in a Hittite Code of Law from $1300 \mathrm{BC}$, and also features prominently in records of the Minoan civilization on Crete, $2^{\text {nd }}$ millennium BC Homer (approximately $800 \mathrm{BC}$ ) mentions honey, and bee-keeping was almost certainly practiced in Greece of the time (Forbes 1957:88-89). In Mesopotamia, Sargon II refers to honey in abundance ( $720 \mathrm{BC})$, but bees for apiculture were probably imported from Hittite territories only in 630 BC (Forbes 1957:86-87). In Italy, when Rome conquered the Etruscans in the $4^{\text {th }}$ century $\mathrm{BC}$, the latter were already involved in apiculture and Rome took it over from them (Forbes 1957:93-96).

China probably first imported bees from Western Asia (and possibly India) in the $5^{\text {th }}$ or $4^{\text {th }}$ centuries BC. Up to the $3^{\text {rd }}$ century BC honey apparently played a minor role in Chinese religion. China made early use of cane sugar (Forbes 1957:79).

Honey was the main sweetener of food in the ancient world, as cane sugar was not yet in popular use. There is evidence that sugar cane was well known in the South Pacific islands in early times, from where China imported it to establish sugar mills as 
early as 2000 BC (Morse \& Hooper 1985:167-169). Other authorities claim that cane sugar originated in northern India and that it was known but not generally used in Mediterranean countries by Hellenistic times (Forbes 1957:100). Dioscorides $\left(1^{\text {st }}\right.$ century $\left.\mathrm{AD}\right)$ referred to it as sakcharon (De materia medica 2.104). It was certainly in popular use in India by the $3^{\text {rd }}$ century.

Egypt

In ancient Egypt honey and dates were the principle food sweeteners. Initially wild honey was used, but when apiculture took root (third millennium BC) large amounts of honey became available. In the economy it was used for tax payment and became a major barter article. It is recorded that pharaoh Thotmes III confiscated large amounts of honey on his campaigns in Syria and Palestine. Ramses II offered the equivalent of 15 tons of honey to the Nile god. Bees and honey played a major role in religious ceremonies, libations to gods, and the bee was associated with royalty and the soul of the dead. "Milk and honey" symbolized affluence. Pure honey was also called "white milk", reserved for royalty and temple use; second grade honey was in general use. Late in Egyptian history honey was used for embalming (Forbes 1957:70-84; Allsop \& Miller 1996:513-520).

The medical papyri (mostly the Ebers Papyrus) record the extensive use of honey as medicine (Nunn 2002:72, 90-148, 160-205; Sigerist 1955:249, 283-287; 337-354). Together with water, milk and wine, honey served as vehicle in many therapeutic preparations, but was also considered a drug in its own right. It was taken by mouth to bring on labour, as purge for intestinal worms and for urinary problems. As linctus or as honey-bread it served as a cough medicine. As local application honey was popular in many eye ointments, often together with a variety of other substances, such as dried faeces from infants, black eye paint, vegetable mucilage, extracts of carob and valerian, and turtle bile. For blindness a mixture of honey, pig's eye humours, and red ochre was poured into the ear. For burns and wounds (including circumcision and human bites), honey was one of many substances applied as bandages. For prolapsed rectum honey, salt and oil was applied, and a painful neck was treated with a mixture containing honey and washerwomen's slops. Complex intravaginal preparations, containing inter alia honey, milk, carob water and other plant extracts, were used to facilitate uterine contraction after birth. Honey and preparations of acacia and carob on lint were placed in the vagina as contraceptives. Honey applications were even utilised in the care of teeth. Today high sugar concentrations are considered bad for teeth. Kyphi was a deodorant containing honey and nine other substances; it was taken by mouth or chewed as a small compact pellet (Algera 2000:43).

\section{Asia Minor and the Semitic world}

Asia Minor was a centre of honey production in the sugarless world of antiquity, well before the $7^{\text {th }}$ century BC. The Hittites in particular were known for their apiculture and bees figured prominently in their myths, e.g. the story of Telipino and 
Hannahannas. About 1300 BC honey was mentioned in Hittite documents, including a Code of Law. Honey was called mil-it, which was also their word for sweet, and is related to melit, the Indo-Germanic word for honey. Bees played an important role in religious ceremonies and were sacred to certain gods. A bee-sting, they believed, could cure paralysis, and honey was a protective agent against certain demons. The mountainous regions of Pontus later acquired a reputation for poisonous honey. The Sanni tribe in Pontus ceased to eat the "bitter and maddening" honey, but continued to collect the beeswax with which they paid their tribute. Andromedotoxin from the Rhododendron-flower was probably responsible for the poisonous honey (Gurney 1990:86-92).

The Bible recalls that for the Israelites returning from Egypt, Palestine was a "land of milk and honey" (Ex. 3:8, 13:5). Originally wild honey was used - apiculture only commenced in the $3^{\text {rd }}$ century BC (Forbes 1957:85-86). Jacob nevertheless had enough honey to use as barter in buying corn from Egypt (Gen. 43:11). In Leviticus 2:11 the Israelites are forbidden to use honey as burnt offerings, but Jonathan replenished his strength during battle by eating wild honey (1 Sam. 14:25-30). The name Deborah means "bee". In Judges 14:8-9 we read about a swarm of bees found in the carcass of a lion killed by Samson. Manna was said to taste like honey-cake (Ex. 16:31). Honey was considered one of life's culinary necessities (Prov. 24:13), although Proverbs 25:16 and 27 warns that eating too much honey will make you vomit. John the Baptist lived from wild honey and locusts (Math. 3:4), and Christ and his disciples ate honey and fish by the lakeside (Luke 24:42). Judah and Israel traded in honey, oil and balsam (Ezek. 27:17). The Bible does not refer to honey as a medicine.

\section{Mesopotamia}

Syrup of dates, not honey, was the preferred food sweetener in ancient Mesopotamia. The word dispu was used for date juice as well as honey which sometimes makes it difficult to decide from literature which one of the two substances is being referred to. However, a popular dish of the time was a mixture of flour, milk and honey. Where mention is made in medical prescriptions of "wild honey" it almost certainly refers to true honey. Honey and butter were used for religious libations (Forbes 1957:86-7; Sigerist 1955:402).

Little use was made of honey in medical treatment. Literature from Ashurbanipal's library mentions a cough mixture containing beer, herbs and honey (Algera 2000:23). A suggested management routine for cleansing yellow teeth consisted of rubbing the teeth with a solution containing turpentine, then washing the nose and mouth with a mixture of beer, oil and honey - after which the patient was induced to vomit (Sigerist 1955:480). Herodotus said that Babylonians buried their dead in honey, but there is no evidence that local nations did in fact use honey in burial procedures (Forbes 1957:87).

Apiculture was almost certainly introduced to Mesopotamia from Hittite Asia Minor in the $7^{\text {th }}$ century BC (Forbes 1957:87). 


\section{The Greek world}

The rather special religious and cultural role which bees and honey played in antiquity, to a large extent derives from their origins in Greek (and subsequently Roman) mythology. It was believed that Zeus (Jupiter), father of the gods, was born on the island of Crete, and under protection of the Great Earth Mother the infant grew up in the cave of Dicte (Mount Ida). He was fed honey by bees and the beautiful Melissa (daughter of Melisseus, king of Crete). Her name became the Greek word for bee. According to Columella (9.2) Zeus actually turned her into a bee. Honey was said to be ros caelestis ("heavenly dew") which fell from the upper air onto flowers, from where bees collected it. It was thus proper to use honey ritually for libations to the dead. Feeding it to children imparted wisdom and eloquence. It was later claimed that the infant Plato, like Zeus, was also fed honey by bees (Price \& Kearns 2003:268).

During the Minoan Civilisation on Crete (c. 3000 - 1000 BC) the bee and honey played a prominent role in religious traditions, particularly so in the cult of Artemis / Britomartis ("Honey-maiden"). Bee-keeping was practiced from an early stage and well established by $1500 \mathrm{BC}$. Bee-hive shaped tholos tombs were seen as "hives of the soul". A popular myth recalled how Glaukos, son of king Minos, fell into a honey-container, to be saved by the seer, Poleidos. The Myceneans (c. 1550-1050 BC) also used honey as offering to the gods (Taylor \& Chadwick 2004:30-33, 296). Homer $\left(9^{\text {th }}\right.$ century BC) refers to apiculture in the Odyssey. Odysseus used beeswax to stop his ears when passing the Sirens (12.173-177), and mead (fermented honey-wine) and milk were offered as libations to the gods. In the Iliad (19.35) the body of Patroclus was preserved in nectar and ambrosia. In Hesiod's vision of the Golden Age, bees (and presumably honey) are associated with oak trees (Works and days 233). Columella recounted various myths about the origin of bees, one being that bees came into existence under Aristaeus (son of Apollo and Cyrene) in Thessaly, who raised them from the carcass of a bull calf. Others claimed that bees originated on Mount Hymettus (in Attica) in the time of Erechteus, mythological king of Athens. Euhemerus (300 BC) said that bees were bred from hornets and reared by nymphs on Cea (island of Cos), while Nicander of Colophon ( $2^{\text {nd }}$ century BC) claimed that they originated on Crete in the time of Saturn. The Pythagoreans were fond of honey and claimed that it promoted longevity (Forbes 1957:88).

Mead ("honey wine", fermented honey) was in popular use. Plutarch (Table Talk 4.5) later said that before man knew wine, he used honey (mead) as drink. It was drunk raw or boiled (when honey was of poor quality), mixed with milk as libation to the dead, and used as medicine (Jouanna 1999:166).

In the Hippocratic Corpus (mostly fifth to fourth centuries BC) honey was prescribed as medicine in many formats, but most commonly as hydromel (honey and water) or oxymel (honey acidified with vinegar).

Hydromel was useful in any acute disease (it was considered more strengthening than wine), as a diuretic and in diluted form as expectorant. In more concentrated preparation it produced loose frothy stools in bilious people, but bound the stools in phlegmatic people. Because it was often given to very weak, even dying 
patients, hydromel gained the quite erroneous reputation of causing debilitation. It was best taken without barley gruel - with gruel it caused abdominal distension, windiness and epigastric discomfort (Reg. 2.53, 56-57; Epid. 5.23). Hydromel was also good for fever and backache, and taken by month for fistula-in-ano (Fist. 3; Epid. 7.8). It could even be used as pregnancy test: if a woman took hydromel without supper, and developed abdominal colic during the night, she was pregnant (Aph. 5.41). Mead was often taken with hydromel.

Oxymel was best taken at night, before gruel, and was most effective for diseases caused by black bile. Taken lukewarm by weak people it depressed expectoration. Oxymel was effective in virtually any illness (Reg. 2.58, 60-61), particularly so in athletes with fever (Epid. 7.9). Undesirable complications included chills in the limbs, flabby bowels with winds passed by mouth instead of per rectum; in women it could cause womb pain (Reg. 2.59).

Taken with beans or as a linctus, honey alleviated difficult labour. Honey cakes gave strength to boxers (Epid. 7.6; 5.71), and alleviated distension caused by overeating (Epid. 7.82). Honey cured a condition with symptoms suggestive of scurvy (Epid. 7.47).

As local application it was of value in haemorrhoids, fistula-in-ano and severe prolapse of the anus (Haem. 2.8; Fist. 3.9). For ulcers a variety of applications were used, prepared by boiling honey in a pot with substances such as turpentine, wine, myrrh, grape juice, bull's gall, nettle shavings and frankincense. Honey-containing plasters were used as styptics (Ulc.12,16,19). Finger infections were treated with oak gall and honey (Epid. 2.6.27). Uterine pessaries were prepared from emmenagogues (drugs stimulating menstruation) and boiled honey (Loc. Hom.47).

Aristotle ( $4^{\text {th }}$ century BC) left us the first extensive (and quite accurate) ancient description of a beehive, its components and activities (HA 8.40-41). He described the wax combs, which besides containing honey, grubs and kerinthos (beebread, pollen stores) was also smeared with mitys (propolis, a brown resinous substance). He noticed that combs had different sections for its three kinds of bees: small worker bees, bigger drones (stingless and sluggish) and relatively static king bees, who flew only when the whole swarm migrated. He noticed robber bees, and said that there were also bright and showy bees, which like women, were lazy! He thought the small worker bees produced the grubs (embryo bees). He noticed certain diseases which affected the hives, and commented on natural enemies like birds, wasps and certain toads. He claimed that bees flying in a wind would carry a pebble as ballast.

Uncertainty about the precise origin of honey continued well into Roman times. One theory was that it fell from the heavens as "aeromeli" onto flowers (Plin. HN 11.12; Verg. Geor. 4.1); others believed it was the sweat of trees (mostly oaks) (Diod. Sic. 17.75; Arist. HA 9.40); some thought it was culled from flowers by bees (Col. 9.14).

Theophrastus $\left(4^{\text {th }}\right.$ century BC) wrote that honey was effective in the topical treatment of wounds and sores ( $C P$ 9.9). When mixed with varieties of tithymallos (splurge) leaves, honey could cure insect bites, dry sores and spleen disorders. 
It was generally accepted that Attic honey was the best in Greek antiquity, but that honey from Salamis, Lesbos and Calymna was also excellent. Corsican honey was considered inferior, Sardinian honey bitter (but not poisonous) and honey from Cos and Cyprus good. Honey from Pontus was considered poisonous (Forbes 1957:88-96). Xenophon (4 ${ }^{\text {th }}$ century BC) reported that his soldiers developed severe intestinal disease, became temporarily mad and even died on eating this honey (An. 4.8.20).

Hellenic Egypt (fourth $-1^{\text {st }}$ century BC) had a strong tradition of apiculture, originating from both Greek and ancient Egyptian sources. There were even specially trained bee-keepers (melissourgoi). The pharaohs had prominent apiaries but did not attempt to monopolise the trade. We read of one Sostratos who owned 1000 hives. Temples also owned apiaries - the "bees of Isis" belonged to the temple of Isis. Aristomachus of Soli (quoted by Pliny the Elder) dedicated 58 years of his life to apiculture. Taxes were levied on both honey and beeswax (Forbes 1957:94-96). Honey was an important foodstuff but also a medicine. In his book On eyes Herophilus prescribes an eye ointment for blindness which contained honey, crocodile dung, hyena bile and vitriolic copper (Von Staden 1994:424).

\section{The Roman world}

Roman knowledge of bee-keeping and honey in Italy originated partly through their contact with the Greeks, but especially the Etruscans who used honey for divination practices, and also as food and a product of trade (Forbes 1957:93-96). Although basic knowledge of bee-keeping had not greatly improved, a number of Roman writers wrote authoritatively on apiculture and the use of honey. Cato's On agriculture $(160 \mathrm{BC})$ was steeped in old traditional views and beliefs, even superstition, but did move into the commercial side of bee-keeping (Morse \& Hooper 1985:168-196).

Although the works of the Spanish born freedman, Hyginus ( $1^{\text {st }}$ century BC) are no longer available, Columella (9.2) considered his contributions on bee-keeping superior to subsequent authors like Vergil and Celsus. Diodorus of Sicily, a contemporary of Hyginus, writing on the eating habits of Nabateans and other Arabs in Syria and Palestine, mentioned "wild honey from the trees" - probably the socalled "tamarisk-manna", a gum which exuded from tamarisk branches after insect damage (Diod. Sic. 19.94).

Vergil ( $1^{\text {st }}$ century BC), wrote his Eclogues and Georgics as pastoral poems, revisiting the mythical Golden Age (inter alia described by Hesiod) and in anticipation of a new Golden Age to come. His Georgics Book 4 (29 BC) is an excellent description of bee-keeping, in which bees are also presented as the model for ideal human behaviour in the coming Golden Age. Like Aristotle he gives a largely accurate description of the structure and function of a bee hive and colony, with its three kinds of bees. He believed that worker bees collected baby bees from scented leaves in nature. The central role of the king bee in stabilizing the colony, is accentuated. Benade (1983:2) believes that the vivid description of a magnificent victorious king bee, in contrast to a pathetic loser bee, was in fact a contemporary 
reference to victorious Octavian, and the conquered Mark Antony. Vergil describes in detail the role played by the expert bee farmer in maintaining a healthy hive, the honey harvesting process and pests which might attack the bee colony. He also refers to the belief that bees could be generated from the carcass of a slaughtered bull calf as originally performed by Aristaeus, on instructions from the gods (Benade 1983:90-105).

Varro completed On agriculture in 37 BC. Books 1 and 2 dealt with general agriculture, and Book 3 included a section on the commercial handling of bees and honey (Morse \& Hooper 1985:158-169).

In his Geography the historian and geographer, Strabo (64 BC - 21 AD), mentioned that savages lived east of Pontus in Asia Minor, of which the Heptacometae were the worst. They were able to prepare "crazing honey" from the exudations of tree branches, which could intoxicate humans. It is recorded that Pompey once lost three cohorts of his army when the Heptacometae overran his incapacitated soldiers, who had eaten their honey (Strabo 12.3.18).

Pliny the Elder (23 - 79 AD) had a great admiration for the bee "created for the sake of man". In describing the comb structure and the remarkable harmony and social organization which characterized a bee colony, he stressed the value of honey and of beeswax (which he claimed had 1000 practical purposes). Pliny recognized the industrious worker bee, the drone (which he considered an imperfect, sterile, servant bee without a sting) and the king bee (without a sting) which would lead the migration to a new hive site. The king's death caused disintegration of the hive. The absence of sexual activity in the hive was noted. He also identified invading gadfly bees and dark robber bees (which he thought were drones) and differentiated between wild and domesticated bees. After stinging, a bee either died or became a drone. He thought honey fell in droplets from the sky at night, to be collected by the bees from plant leaves. "Bee bread" he thought, originated from fig trees. He differentiated between spring honey, summer honey and inferior wild honey in autumn (HN 11.4-19).

Columella wrote his On agriculture in 60-65 AD as 12 books on farming, of which Book 9 deals inter alia with bees. He wrote as a successful practical farmer deeply concerned about the decline of Italian agriculture. His work on bees is based on his own experience, enriched by myths, as well as Greek and earlier Roman literature. His very practical approach to bee-farming includes a review of the kinds of bees available, correct feeding grounds, location of apiaries (away from foul smells, even human perfume), exclusion of pests and predators, day to day care of the bee colony, and harvesting of honey. The different kinds of bees present in the hive are described with emphasis on the king bee(s). He mentions the possibility of generating bees from a bull calf carcass, but states that this is rarely necessary.

In his De materia medica, Pedanius Dioscorides of Anazarbus $\left(1^{\text {st }}\right.$ century $\mathrm{AD}$ ), greatest pharmacologist of Roman times, included a section on honey. It was normally harvested in early May, in mid-September and November; he considered spring-honey the best, and winter honey (which could cause skin wheals and blisters) the worst. Attic honey (Hymettic) was best and the next best came from Sicily (Hyblaean). As treatment, honey opened pores and extracted liquids; it was best 
boiled before being used as medicine. It was effective as a local application on circumcision wounds, sores and lichen, on fungus infections, and for snake and mad dog bites. Sardinian honey (bitter, because bees fed on wormwood shrubs) and Heraclean honey from Pontus were good for sunburn and bruises; the latter taken orally, could cause severe perspiration. Honey could be taken internally for pain and noise in the ears, coughs or urinary stoppage. For a painful throat, honey could be rubbed on, or gargled (2.82.1-5). Mead (honeyed wine, mulsum) made by adding wine or must to honey, was particularly effective as diuretic, mover of the bowels and appetizer in elderly people. When taken after meat, it caused abdominal pain (5.8).

Dioscorides knew sugar reeds (sakcharon) as the origin of a kind of "coalesced honey", called sugar, and obtained from India and neighbourly Arab countries (2.82.5).

Celsus' De medicina ( $1^{\text {st }}$ century AD) indicates that in his day honey (and mead) was used very extensively as medicine, usually in combination with a large number of other substances, both internally and as topical applications. Much of this is clearly based on Hippocratic medicine. Honey was said to move the bowels, be an emetic, be nutritious in fevers, an astringent (when old honey was boiled in a leaden pot) and of value with difficult micturition (1.1.3, 1.2.28, 1.3.6, 1.4.26, 2.5.25); taken with cheese or pea gruel it confined the bowels (1.2.30, 4.26). As hydromel (aqua mulsa) it was a purge, effective in phrenitis, fever, jaundice pleurisy and lung infections and lethargy $(1.2 .12,1.3 .18,20,24,26,1.4 .13-14)$. In combination with wormwood, hyssop (and other plant materials) it cleared the bowels of intestinal worms (1.4.24). Oxymel (honey and vinegar) was also a popular medicine (1.3.27). Externally (with or without other ingredients) honey was applied to wounds to the genitalia in hysteria $(1.4 .26 ; 2.5 .1)$, and with rose oil to sooth a painful tongue (1.3.10). With or without goat's bile it served as eye ointment for trachoma (2.6.6). Honey was included in clysters for abdominal pain and jaundice, and in a gargle for sore throat (angina) $(1.4 .7,19,1.3 .24)$. The popular ointment, ceratum, consisted of beeswax and honey (2.4.27).

Galen of Pergamon ( $2^{\text {nd }}$ century), giant of Roman medicine as well as succeeding physicians, used honey extensively but added little to its medicinal use in his Opera omnia. His Hiera picra Galeni (still used in the $17^{\text {th }}$ century) consisted of honey, aloe, saffron and cinnamon. It was very bitter and taken internally acted as a laxative; it could also cure virtually all abdominal problems (including worm infestation) and menstrual abnormalities (Algera 2000:94; Hajar 2002: 11). Palladius ( $4^{\text {th }}$ century), a knowledgeable agriculturist, wrote on apiculture with extensive reference to Columella and other preceding Roman authors (Morse \& Hooper 1985:169).

\section{Bees and honey today}

The honey bees of antiquity in Mediterranean countries were almost certainly of the species, apis mellifera, still in existence today (Morse \& Hooper 1985:41). As recognized by authors of Classical times a beehive contains three kinds of adult bees: 
(1) Worker bees (the vast majority) are females, but will lay eggs very exceptionally; lifespan 33-35 days in summer, 4-5 months in winter.

(2) Drones, larger than worker bees, are males; mating with the Queen bee is their only task and they are fed by worker bees; lifespan approximately 60 days, when they are evicted by the worker bees.

(3) Queen bees (erroneously called king bees in antiquity), the same size as drones, live for up to 3-4 years; as fully competent females, they can lay approximately 1500 eggs per day, after mating with drones. Fertilised eggs produce queen bees and worker bees, and unfertilised eggs, drones.

Bees feed on honey and pollen (Morse \& Hooper 1985: 45, 102-103, 242, 310-319, 417). Honey is formed by the action of enzymes (from the bee's hypopharangeal glands) on nectar, collected from flowers. Bees also collect sweet saps emanating from injuries to certain plants and trees, and store it in the hives with the honey, socalled "honey dew" (Morse \& Hooper 1985:180). Storage pollen in hives is known as "bee-bread". Hives are constructed from beeswax, secreted by the wax-glands of worker bees. Wax surfaces are smeared with protective propolis - a resinous substance collected from exudates on trees (Morse \& Hooper 1985: 40-46).

The quality of honey varies in different areas, depending on the nectar collected by the bees. Honey consists predominantly of sugars (fructose $38 \%$, glucose $31 \%$, sucrose $1 \%$ ), water, minute amounts of minerals and vitamins (nutritionally insignificant), enzymes (e.g. hydrogen-peroxide), 18 free amino acids (essential for bees) and traces of pollen and other contaminants. It is mildly acidic, with $\mathrm{pH} 3,5-4,0$ (Morse \& Hooper 1985:180-183; Hamilton, Whitney, Sizer 1988:72, 99). A serious pollution may be contamination with spores and toxin of Clostridium botulinum. The concentration of botulinum toxin is too low to injure adults, but it has the potential to kill infants under one year of age, who should not eat honey (Hamilton, Shitney, Sizer 1988:394, 412; Druyff 2002:385).

It is today known that honey does not contain the wide spectrum of healing properties ascribed to it in antiquity. However, the authoritative Martindale pharmacopoeia still lists honey as a demulcent, sweetener, and component of cough mixtures, a bacteriostatic gargle, and various tonics (Hamilton, Whitney, Sizer 1988:394, 412; Druyff 2002:385.). It is perhaps best known for its value as a topical antiseptic agent. Various reports have acclaimed its efficacy as antibacterial ointment in burns, chronic ulceration and surgical wounds (Hajar 2002:1-21; Molan \& Allen 1996:1206-1209). Although pathogens like salmonella and shigella survive in honey for months to years, in vitro studies, showing it to have significant bacteriostatic effects, have also been published. The antibacterial action of honey is thought to emanate from its acidity, its high osmolarity and the enzyme hydrogen-peroxide. Molan and co-workers in Australia found that "manuka honey" (but not other honeys tested) has a significant antibacterial action, attributed to an as yet undiscovered therapeutic factor in the product (Molan \& Allen 1996:1207-1209; Molan \& Allen 1998:27, 62-67). Claims that honey facilitates wound healing, has anti-allergic, antiarthritic and sedative qualities are unproven (Hamilton, Whitney \& Sizer 1988:412414; Passmore \& Eastwood 1986:197). As nutrient honey and sugar are virtually 
identical; honey delivers 65 calories energy per teaspoon - a little more than white sugar does (Hamilton, Whitney \& Sizer 1988:412-412).

\section{Discussion}

Dedicated bee-keeping (apiculture) and harvesting of honey goes back at least 4500 years. It originally carried a strong religious connotation, except with the Jews (where the offering of honey was forbidden) and probably the Chinese, where honey played a minor role in their religious literature. In addition to being an object of divine reverence, honey was a food and major sweetener (except in ancient Mesopotamia where dates was the main sweetener), a luxury item (even counting as money in the barter trade) and a popular medicine.

The authors mentioned above, who left detailed descriptions of the structure and function of bee-hives, were well informed. Most commented specifically on the orderly social structure within such a hive, and the poet Vergil suggested that the populace of the expected new Golden Age for man would replicate the prosperous and co-operative vital force characteristic of a bee colony. However, their biological facts about bees did understandably contain errors. The extensive role of small worker bees was appreciated, but what they described as the central king bee, was of course a queen bee, responsible for laying eggs. Vergil suggested that bee embryos were collected from scented leaves by worker bees while Aristotle said worker bees gave origin to embryos. Drone bees were recognized but their role was not understood. Pliny thought they developed from worker bees who had lost their stings; Columella suspected drones played a role in the hatching of bee-eggs. Aristotle said some worker bees were "bright and showy", but they were also lazy, like women. (This comment would reflect Aristotle's known views about the inferiority of women.) Columella thought bees could reach the age of ten years, and Vergil suggested seven years. Queen bees may live a few years, but other bees live only for a few months (Morse \& Hooper 1985:242-243). There is no truth in the statement by various authors that bees flying in the wind, carried pebbles as ballast. The myth that bees could be generated from the carcasses of bull calves, is repeated as fact by Vergil and Columella. An interesting parallel to this belief is the Old Testament story of Samson, finding a swarm of bees in the carcass of a lion he had previously killed (Judges 14: 8-9).

In Classical times it was accepted that honey differed from region to region. In the Greek world Attic honey was best, honey from Salamis, Lesbos, Calymna, Cos and Cyprus good, but honey from Corsica, Sardinia and Pontus (Northern Asia Minor) considered inferior, even poisonous. Although Dio Chrysostomus called Pontic honey "sharp" only, and Dioscorides said that it caused marked perspiration, there are prominent reports that it was actually poisonous. The army of Xenophon $\left(4^{\text {th }}\right.$ century BC) found that it caused severe intestinal problems, temporary insanity, even death. Three centuries later a section of Pompey's army was overrun by the savage Heptacomitae after the soldiers lost their senses drinking "crazing honey" prepared by the Heptacomitae. In both episodes there is evidence of mental derangement, which Forbes suggests was caused by andromedotoxin, present in the flowers of the local 
rhododendron plant. Pliny also wrote that at a certain time of the year honey from Pontus was poisonous, and that cattle and goats died from eating aegolethron plants (HN 21.71-74). Strabo (12.3.18) said that the "crazing honey" was derived from treetwigs, raising the possibility that it could have been so-called "honey dew" rather than true honey. As described above bees may collect sweet substances exuding from damaged plants / trees, and deposit it with regular honey in the beehives (as "honey dew"). One of the earliest theories of the origin of honey was indeed that bees culled it directly from trees (oaks in particular) - and that honey could occasionally drip from leaves and twigs. The "tamarisk-manna" described by Diodorus of Sicily was almost certainly an example of sweet, honey-like substances exuding from tamarisk trees, and not true honey.

As discussed above, few of the many medical uses of honey assumed in antiquity can be verified today. Honey was rarely used alone, but in combination with a large number of other substances, even including bizarre products like crocodile dung, hyena bile, foetal faeces, washerwomen's slops, tortoise gall and pig's eye. Estimating the specific healing value of honey in such mixtures would be impossible. Honey containing medicaments were used in a wide variety of illnesses - internally, as gargles, pessaries or clysters, and as topical applications. Honey and water was even used as a pregnancy test. The Hippocratic Corpus generally prescribed simpler honey preparations with hydromel (honey and water), oxymel (honey and vinegar) and mead (honey wine) the most popular. In modern pharmacopoeias honey can still be found in cough mixtures, gargles and tonics, and the names oxymel and hydromel are still used. From a scientific point of view there is evidence that topical applications containing certain kinds of honey have bacteriostatic effects. As sweetener and nutrient it has little advantage over sugar. Because of the proven possibility of pollution by Clostridium botulinum spores, honey should not be fed to infants under the age of one year.

\section{BIBLIOGRAPHY}

Algera, M 2000. Mens en Medic̈̈n. Amsterdam: Meulenhof.

Allsop, K A \& Miller J B 1996. Honey revisited. British Journal of Nutrition 75: 513-520.

Ash, H B (trans.) 1941. Columella. On agriculture. Loeb Classical Library Vol. I. Cambridge MA: Harvard University Press.

Balme, D M 1991 (trans.). Aristotle. History of Animals. Loeb Classical Library Vol XI. Cambridge MA: Harvard University Press.

Beck, L Y (trans.) 2005. Pedanius Dioscorides of Anazarbus. De Materia Medica. Hildesheim: Olms-Weidmann

Benade, J T 1983. Vergilius, Eclogae en Georgica. Pretoria: Universiteit van Suid Afrika.

Blacow, N W (ed.). 1972. Martindale Pharmacopoeia. $26^{\text {th }}$ ed. London: Pharmacology Press. 
Browson, C L (trans.) 1998. Xenophon. Anabasis (revised by J Dillery). Loeb Classical Library Vol. III. Cambridge MA: Harvard University Press.

Clement, P A \& Hoffleit, H B (trans.) 1969. Plutarch. Table Talk. Loeb Classical Library Vol. VIII. Cambridge MA: Harvard University Press.

Druyff, R L 2002. Complete Food and Nutritional Guide. Hoboken, NJ : John Wiley $\&$ Sons.

Evelyn-White, H G 1914. Hesiod. Homeric Hymns. Epic Cycle. Homerica. Loeb Classical Library. Cambridge MA: Harvard University Press

Fairclough, H R (trans.) 1916. Virgil. Eclogues. Georgics. Aeneid Books 1-6. Loeb Classical Library. Cambridge MA: Harvard University Press.

Forbes, R J 1957. Studies in Ancient Technology. Vol. V. Leiden: E J Brill Publishers

Forster, E S (trans.) 1954. Columella. De agricultura. Vol. II. Loeb Classical Library. Cambridge MA: Harvard University Press.

Gurney, O R 1990. The Hittites. London: The Folio Society. R J Forbes.

Hajar, R 2002. Honey from Folklore to Medical Marvel? Heart Views 3/4:5-6.

Hamilton, E N N, Whitney, E N \& Sizer, F S 1988. Nutrition. St. Paul's: West Publ. Co.

Hammond, M (trans.) 1987. Homer. The Iliad. London: Penguin Books.

Hooper, W D \& Ash, H B (trans.) 1934. Cato and Varro. On agriculture. Loeb Classical Library. Cambridge MA: Harvard University Press.

Hort, A F (trans.) 1916. Theophrastus. Enquiry into Plants. Loeb Classical Library Vol. II. Cambridge MA: Harvard University Press.

Johnson, P 1980. Vergil's Agricultural Golden Age: A Study of the Georgics. Leiden: E J Brill Publishers.

Jones, H L (trans.) 1928. Strabo. Geography. Loeb Classical Library Vol. V. Cambridge MA: Harvard University Press.

Jones, W H S (trans.) 1931. Hippocrates. Regimen. Aphorisms et al. Loeb Classical Library Vol. IV. Cambridge MA: Harvard University Press.

Jouanna, J 1999. Hippocrates. Trans. M B de Bevoise. Baltimore: Johns Hopkins University Press.

Molan, P C \& Allen, K L 1996. The effect of gammairadiation on the antibacterial activity of honey. Journal of Pharmacy and Pharmacology 48:1206-1209.

Molan, P C \& Allen, K L 1998. Non-peroxide antibacterial activity in some New Zealand honeys. Journal of Apicultural Research 27:62-67.

Morse, R \& Hooper, T 1985. The Illustrated Encyclopaedia of Beekeeping. Sherborne U.K. Alphabooks.

Nunn, J F 2002. Ancient Egyptian Medicine. Norman: Univ. Oklahoma Press. 90-148, 160-205.

Passmore, R \& Eastwood, M A 1986. Human Nutrition and Dietetics. Edinburgh: Churchill Livingstone.

Potter, P (trans.) 1995. Hippocrates. Places in Man. Fistulas. Ulcers. Haemmorrhoids et al. Loeb Classical Library Vol.VIII. Cambridge MA: Harvard University Press.

Price, S \& Kearns, E 2003. Oxford Dictionary of Classical Myth and Religion. Oxford: University Press. 
Rackham, H (trans.) 1940. Pliny. Natural History. Loeb Classical Library Vol. III. Cambridge MA: Harvard University Press.

Rieu, E V 1991. Homer. The Odyssey (revised by D C H Rieu \& P V Jones). London: Penguin Books.

Rizza, R A \& Go, Y L 2002. Encyclopedia of Foods. San Diego: Acad. Press.

Sigerist, H E 1955. A History of Medicine. New York: Oxford University Press.

Smith, W D (trans.) 1994. Hippocrates. Epidemics et al. Loeb Classical Library Vol. VII. Cambridge MA: Harvard University Press.

Spencer, W G (trans.) 1935. Celsus. De Medicina. Loeb Classical Library Vol. I. Cambridge MA: Harvard University Press.

Taylour, W \& Chadwick, J 2004. The Mycenaeans. London: The Folio Society.

Von Staden, H 1994. Herophilus. Cambridge: University Press.

Welles, C B (trans.) 1963. Diodorus Siculus. Library of History. Loeb Classical Library Vol. VIII. Cambridge MA: Harvard University Press. 